\title{
RT-qPCR assay for detection of British (B.1.1.7) and South Africa (B.1.351) variants of SARS-CoV-2
}

Karin Yaniv ${ }^{1 \dagger}$, Eden Ozer ${ }^{2 \dagger}$, Noam Plotkin ${ }^{1}$, Nikhil Suresh Bhandarkar ${ }^{1}$ and Ariel Kushmaro ${ }^{1,3 *}$

$\dagger$ These authors contributed equally

${ }^{1}$ Avram and Stella Goldstein-Goren, Department of Biotechnology Engineering, BenGurion University of the Negev, Beer-Sheva, Israel.

${ }^{2}$ Department of Life Sciences, Ben-Gurion University of the Negev, Beer-Sheva, Israel.

${ }^{3}$ The Ilse Katz Center for Meso and Nanoscale Science and Technology, Ben-Gurion University of the Negev, Beer Sheva 8410501, Israel.

* Corresponding author 


\begin{abstract}
Less than a year following the SARS-CoV-2 outbreak, variants of concern have emerged in the form of the British variant B.1.1.7 and the South Africa variant B.1.351. Due to their high infectivity and morbidity, it is crucial to quickly and effectively detect them. Current methods of detection are either time-consuming, expensive or indirect. Here, we report the development of a rapid, cost-effective and direct RT-qPCR method for detection of the two variants of concern. We developed and validate a detection system for the detection of the B.1.1.7 variant and another single detection set for the B.1.351 variant. The developed approach was characterized and tested on wastewater samples and illustrated that all primers and probes were sensitive and specific. The novel system presented here will allow proper response and pandemic containment with regard to these variants. In addition, it may provide a basis for developing tools for the detection of additional variants of concern.
\end{abstract}


medRxiv preprint doi: https://doi.org/10.1101/2021.02.25.21252454; this version posted March 1, 2021. The copyright holder for this preprint (which was not certified by peer review) is the author/funder, who has granted medRxiv a license to display the preprint in perpetuity.

\section{Introduction}

The SARS-CoV-2 world pandemic erupted early 2020 with rising numbers in morbidity and mortality. SARS-CoV-2 was recognized as an RNA virus, therefore detection methods emerging for immediate response were mainly in the form of reverse transcriptase quantitative polymerase chain reaction (RT-qPCR) (Lu et al., 2020). In RT-qPCR, RNA is extracted, undergoes reverse transcription for DNA strand generation, followed by PCR amplification and TaqMan probes fluorescence detection. To date, RT-qPCR is the most common methodology for SARS-CoV-2 diagnostics (Vogels et al., 2020).

Starting in September 2020, new variants of concern of SARS-CoV-2 virus began to emerge. Amongst them, the variants termed the British variant B.1.1.7 and South Africa (SA) variant B.1.351 became dominant compared to the original SARS-CoV-2 virus (Wang et al., 2021). Due to their higher infection rate and high morbidity, identification of these variants became essential. A diagnostic tool that could quickly and efficiently distinguish between the variants is imperative to help evaluate the variants' distribution. Proper "variant mapping" will provide much needed information to enforce appropriate policy for pandemic containment.

Currently, three methodologies have been developed for SARS-CoV-2 variant diagnostics. The first methodology, that is still mainly being employed, is the next generation sequencing (NGS) approach (Andrés et al., 2020; Khan et al., 2020). In NGS the entire variant's genome is sequenced. Despite demonstrating the importance of this technique for identification of new variants, its use on previously sequenced variants is time-consuming and requires significant financial means.

Additional detection methods are based on RT-qPCR and include a "drop-out" signal, available in commercial kits (such as TaqPath COVID-19 diagnostic tests, Thermo Scientific, Helix ${ }^{\circledR}$ COVID-19 Test) or a method published in a recent study (Vogels et al., 2021). These use RT-qPCR with two different markers, a double signal manifest for the original SARS-CoV-2 virus, while only a single signal manifest for the targeted variant. Another detection methodology is through characterization of $\Delta \mathrm{Ct}$ between one detection signal and another amongst the different variants (Kovacova et al., 2021). Thus theses current RT-qPCR approaches for variant detection, though significantly faster and cost-effective than the NGS methodology, focuses on indirect detection and may result in false/inconclusive identification. 
medRxiv preprint doi: https://doi.org/10.1101/2021.02.25.21252454; this version posted March 1, 2021. The copyright holder for this preprint (which was not certified by peer review) is the author/funder, who has granted medRxiv a license to display the preprint in perpetuity.

All rights reserved. No reuse allowed without permission.

Therefor there is still a great need for a quick improved specificity- and sensitivity SARS-CoV-2 variants detection methods. Such advanced methodologies will be amenable for clinical diagnostics, as well as for environmental-derived quantification, greatly improving wastewater and population level epidemiology. In this study, we developed a RT-qPCR assay for the direct detection of SARS-CoV-2 British variant B.1.1.7 and another set of RT-qPCR primersprobe for the detection of SARS-CoV-2 SA variant B.1.351. Our design was tested on S gene deletion and non-deletion DNA templates and RNA originating from wastewater samples to assess the sensitivity and specificity of the described sets.

\section{Methods}

Primers and probes design

The original sequence of SARS-CoV-2 (NC_045512.2) was taken from NCBI database. British B.1.1.7 variant (EPI_ISL_742238) and SA B.1.351 variant (EPI_ISL_736935) sequences were taken from GISAID database (Shu and McCauley, 2017). The probe design focused on the S gene 21724-21828 bp location that includes the British deletion 69-70 or S gene 22243-22331 bp location that includes the SA deletion 241-243. All primers and probes were purchased through Integrated DNA Technologies (IDT). ZEN Quencher was added to the probes as a second, internal quencher in qPCR 5'-nuclease assay. To allow a possibility for duplex assay, S1 probe was assigned a 6-carboxy-fluorescein (FAM) fluorophore and $\mathrm{S} \Delta 69$ probe was assigned to Yakima Yellow (YakYel) fluorophore. S $\Delta 241$ probe was assigned with FAM as well.

\section{$R T-q P C R$}

RT-qPCR was executed using One Step PrimeScript III RT-qPCR mix using standard manufacture protocol (RR600 TAKARA, Japan). Each reaction mixture contains primers $(0.5$ $\mu \mathrm{M}$ each), probe $\left(0.2 \mu \mathrm{M}\right.$ each), ROX reference dye and $5 \mu \mathrm{L}$ of DNA or RNA $\left(\mathrm{dH}_{2} \mathrm{O}\right.$ was added to a final volume of $20 \mu \mathrm{L}$ reaction volume). RT-qPCR amplification was executed using Step One Plus real-time PCR system (Applied Biosystems, Thermo Scientific). In addition to what is described above, in each run all RT-qPCR experiments included quality controls. The first control was using water sample instead of DNA/RNA (Non template control (NTC)). The second control, used for RNA extractions, was MS2 phage detection (Dreier et al., 2005). 
medRxiv preprint doi: https://doi.org/10.1101/2021.02.25.21252454; this version posted March 1, 2021. The copyright holder for this preprint (which was not certified by peer review) is the author/funder, who has granted medRxiv a license to display the preprint in perpetuity.

All rights reserved. No reuse allowed without permission.

\section{Calibration curves and limit of detection determination}

Calibration curves were performed on a known-positive DNA gene block. Two different gene blocks were used; one containing SARS-CoV-2 S gene sequence as reported for WuhanHu-1 (NC_045512.2), the second containing S gene sequence matching the reported 69-70 deletion of the British variant (B.1.1.7) as well as the reported 241-243 deletion of the SA variant (B.1.351). Calibration of S1 probe was performed using S gene sequence from NC_045512.2, while calibration of $\mathrm{S} \Delta 69$ probe and $\mathrm{S} \Delta 241$ was performed using $\mathrm{S}$ gene sequence with the relevant deletions. Serial dilutions for the relevant gene block were prepared based on copy number calculations. The resulted $\mathrm{Ct}$ values were plotted against the log copy number of the $\mathrm{S}$ gene template. Linear regression was performed between the log copy number and the Ct values from the RT-qPCR results.

\section{Wastewater RNA extraction}

For wastewater sampling, composite sewage samples from the wastewater treatment plant (WWTP) were immediately transferred to the lab under chilled conditions. The samples were kept at $4^{\circ} \mathrm{C}$ until processed. Direct RNA was extracted according to manufacture protocol as it describes in NucleoSpin RNA extraction kit (Macherey Nagel, Germany). An amount of $10^{5}$ copies of the phage was added to the lysis buffer in each RNA extraction for inner control. RNA was eluted with $50 \mu \mathrm{L}$ of RNase free water and kept at $-80^{\circ} \mathrm{C}$.

\section{Complex matrix detection}

Extracted RNA from wastewater sample, known to be SARS-CoV-2 negative, was supplemented with known concentrations of a desired gene block. The samples underwent the same RT-qPCR conditions as described for the calibration curves. Results were plotted to represent the new probes limit of detection in a complex environment.

\section{Results and Discussion}

Developing our assay, we focused on the most dominant variants of SARS-CoV-2 currently known. These, the British variant B.1.1.7 and South Africa (SA) variant B.1.351, were deemed the most urgent variants in need for fast detection. Our design for RT-qPCR detection assays of the two variants (Figure 1), is based on the differences in the $\mathrm{S}$ gene from the original 
sequence (NC_045512.2). B.1.1.7 S gene contains a deletion known as $\Delta 69-70$ and B.1.351 $\mathrm{S}$ gene contains a deletion known as $\Delta 241-243$. Accordingly, our designed focused on these regions.
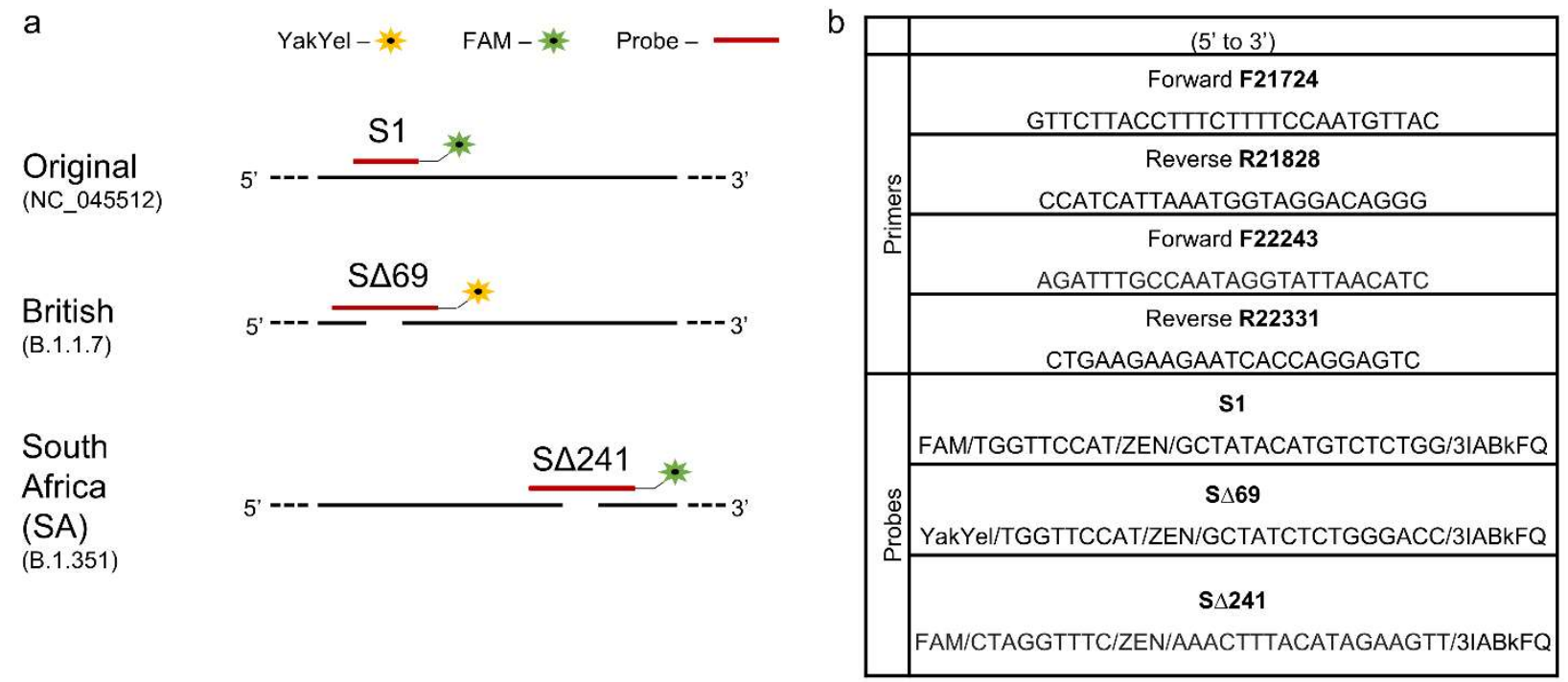

Figure 1: (a) Designed detection set for differentiation and identification of SARS-CoV-2 British variant B.1.1.7 and South Africa variant B.1.351. (b) List of primers and probes sequences.

For B.1.1.7 detection, the designed detection set is located at the $\mathrm{S}$ gene 21724-21828 bp of the original sequence. Within this range, the original SARS-CoV-2 and B.1.1.7 sequences are completely identical, apart from 6 nucleotides deletions (Fig. 1a). Our main attempt was to create two separate detections to the amplified area, one corresponding to the original sequence (when using $\mathrm{S} 1$ probe) and the other corresponding to the B.1.1.7 (when using the $\mathrm{S} \Delta 69$ probe). Using designated primers (Fig. 1b) to amplify the specified region surrounding the 6 nucleotides differences, an amplification will be generated regardless to the variant. The probes can thus be used in a single duplex assay via separate wavelengths, where a signal signifies a direct detection of either the original sequence or of B.1.1.7.

For B.1.351 detection, the designated detection region was chosen further along the $\mathrm{S}$ gene when compared to the B.1.1.7 detection region. Focusing on S gene 22243-22331 bp of the original sequence, the original SARS-CoV-2 sequence is identical to the B.1.351 sequence apart from a 9 nucleotides deletion (Fig. 1a). Using a detection set comprised of two primers meant to amplify the target region, a single probe ( $\mathrm{S} \Delta 241$ probe) was designed for the detection of the B.1.351 variant. The $\mathrm{S} \Delta 241$ probe is meant to correspond only to the deletion of 9 nucleotides in 
the specified region, characterizing B.1.315, therefore will signal detection only when B.1.351 is present and will not correspond to the original sequence.

To ensure functionality, the described sets of primers and probes underwent characterization. Initially, a calibration curve was generated for primers with the relevant probe separately, using dsDNA as a template. A detection range of between $10^{7}$ copies and ten copies per $\mu \mathrm{L}$ was tested for each probe. Results plotted for both probes confirmed the chosen primers' (4 different primers, 2 different amplification sets) ability to amplify the target region (Fig. 2). Furthermore, linear regression performed for both probes demonstrated strong coloration and the probes validity for usage on the amplified fragment. A limit of detection (LOD) could be determined for each probe and was identified as $10^{1}$ copies per $\mu \mathrm{L}$ for all three probes.

$\mathrm{S} \Delta 69$

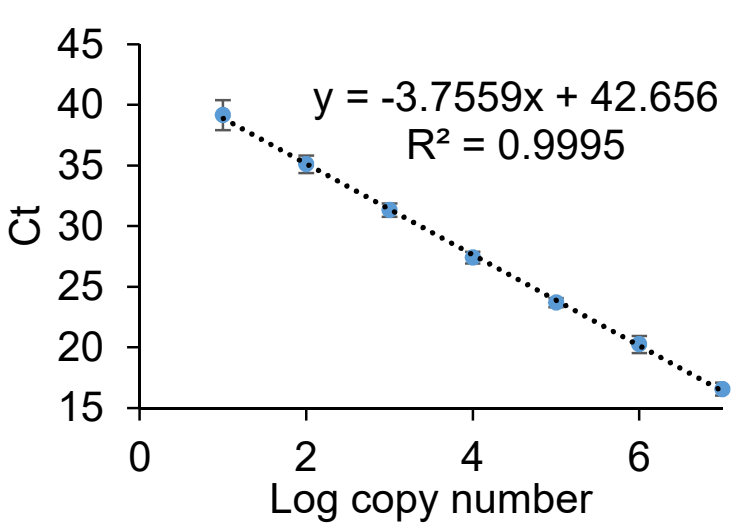

$\mathrm{S} \triangle 241$

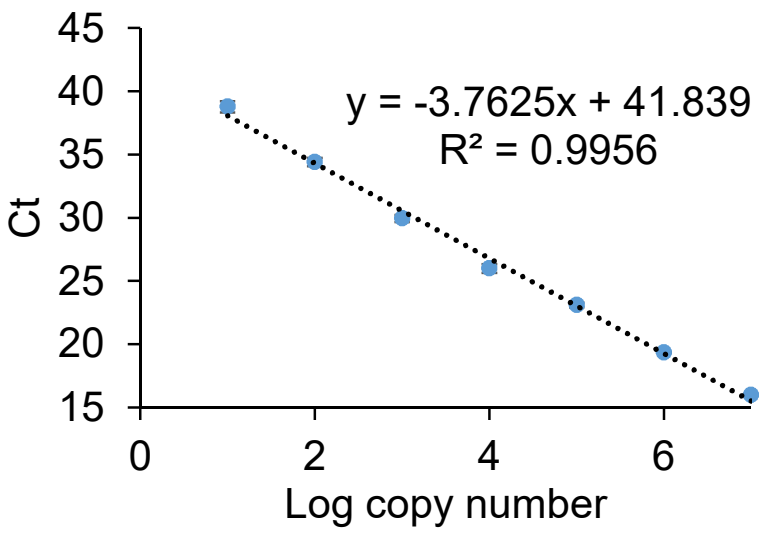

S1

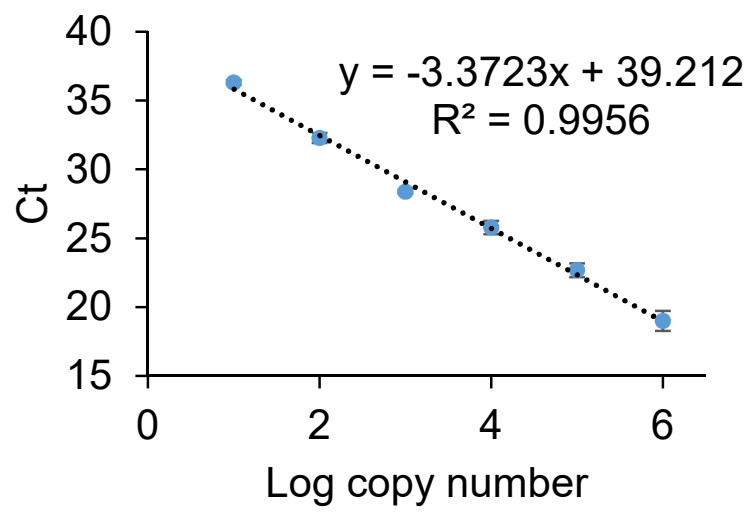

Figure 2: calibration curves and limit of detection of $\mathrm{S} \Delta 69$ probe, $\mathrm{S} \Delta 241$ probe and $\mathrm{S} 1$ probe.

Following basic characterization, further confirmation to the described methodology was performed using a more complex environment for the RT-qPCR reaction. As SARS-CoV-2 
medRxiv preprint doi: https://doi.org/10.1101/2021.02.25.21252454; this version posted March 1, 2021. The copyright holder for this preprint (which was not certified by peer review) is the author/funder, who has granted medRxiv a license to display the preprint in perpetuity.

All rights reserved. No reuse allowed without permission.

wastewater detection is important with regards to the development of a quick early warning system for virus detection during the global pandemic (Bar-Or et al., 2020), wastewater matrix collected from wastewater treatment plant at the city of Beer Sheva, Israel, was chosen as complex environment. All three probes were employed on wastewater samples pre-determined as negative for SARS-CoV-2 with various dsDNA template copies (Fig. 3). As can be seen in Figure 3, despite the wastewater matrix, the 3 designed probes displayed high detection sensitivity. With the ability to detect up to $10^{1}$ copies per $\mu \mathrm{L}$, the new probes demonstrated satisfying detection ability when compared to previously described primers and probes sets for clinical diagnostics (Vogels et al., 2020).

$S \triangle 69$

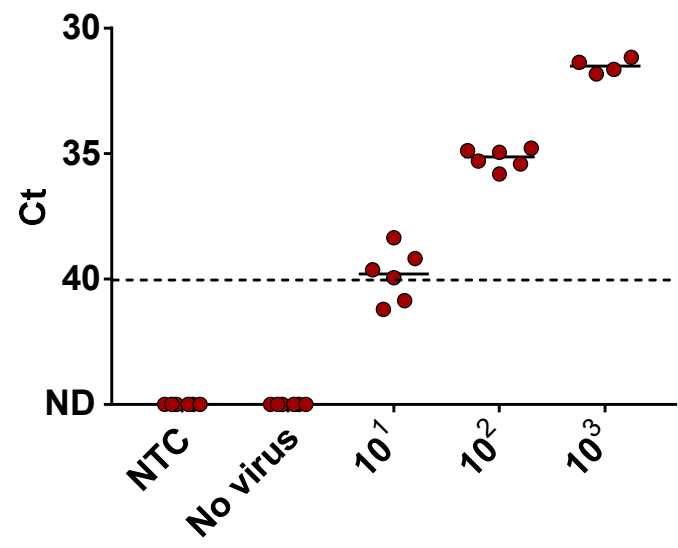

$\mathbf{S} \Delta \mathbf{2 4 1}$

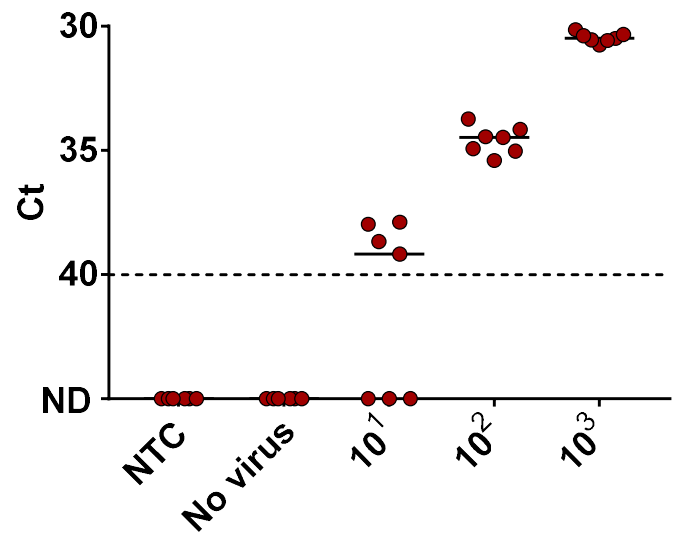

S1

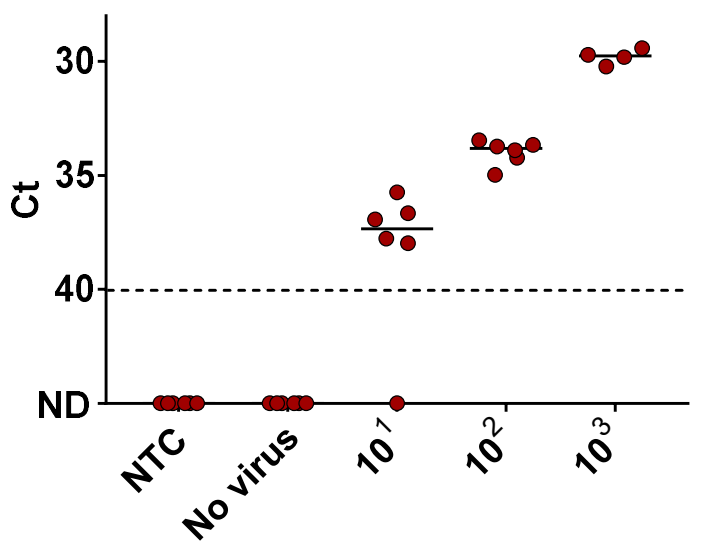

Figure 3: Lower detection limit of $\mathrm{S} \Delta 69, \mathrm{~S} \Delta 241$ and $\mathrm{S} 1$ primer-probe sets in wastewater matrix. RNA extracted from negative detection wastewater sample (No virus) spiked with known concentrations of SARS-CoV-2 S gene template $\left(10^{1}-10^{3} \mathrm{~S}\right.$ gene template copies $\left.\mu \mathrm{l}^{-1}\right)$ and Non-Template Control (NTC, water). For $\mathrm{S} \Delta 69$ probe and $\mathrm{S} \Delta 241$ probe, the $\mathrm{S}$ gene deletion template corresponded to $\Delta 69-70$ deletion site in British B.1.1.7 and $\Delta 241-243$ deletion site in South Africa B.1.135. For S1 probe, the S gene template corresponded to NC_045512.2 sequence. ND - not detected. Solid lines indicate the median and dashed lines indicate the detection limit as decided by clinical guidelines. 
medRxiv preprint doi: https://doi.org/10.1101/2021.02.25.21252454; this version posted March 1, 2021. The copyright holder for this preprint (which was not certified by peer review) is the author/funder, who has granted medRxiv a license to display the preprint in perpetuity.

To examine the probes specificity and rule out possible false-positive cases, each probe was tested with a negative control. For S1 probe, the negative control was comprised of a dsDNA template with the $\mathrm{S}$ gene with $\Delta 69-70$ and $\Delta 241-243$ nucleotides deletions. While for $\mathrm{S} \Delta 69$ probe and $\mathrm{S} \Delta 241$ probe, the original $\mathrm{S}$ gene sequence was used as negative control. As expected, none of the probes manifested a signal in the presence of a negative control and nonspecific detection was not observed (Table 1).

Finally, the three probes, S, S $\Delta 69$ and $\mathrm{S} \Delta 241$ were tested on wastewater samples (Table 1). Moreover, the CDC's N2 detection set was used as standard detection reference that can correspond to each of the variants (Lu et al., 2020). According to the results, samples collected at November-December 2020 (prior to the B.1.1.7 outbreak in Israel) resulted in a positive signal from the $\mathrm{S} 1$ probe, while there was no signal from $\mathrm{S} \Delta 69$ probe or $\mathrm{S} \Delta 241$ probe. A later sample from February 2021 (B.1.1.7 was already present in Israel), resulted in a different result, as S $\Delta 69$ probe revealed positive detection, while S1 probe and S $\Delta 241$ showed no detection signal. This meant that most likely the wastewater sample from November 2020 was positive only for the original SARS-CoV-2 (NC_045512.2), while the wastewater sample from February 2021 was positive only for B.1.1.7 variant. Considering that B.1.351 variant was not detected in Israel at that time, the results matched our expectations and the $\mathrm{S} \Delta 241$ probe did not detect any signal in any of the wastewater samples.

Looking at the detection results from wastewater from Beer-Sheva, Israel, an interesting observation was seeing that the $\mathrm{N}$ gene detection constantly produced lower $\mathrm{Ct}$ values compared to the $\mathrm{S}$ gene detection (with either $\mathrm{S} 1$ probe or $\mathrm{S} \Delta 69$ probe). This may imply different gene expression distributions or different durability of the RNA segments, however this needs further study and validation to better understand such an observation. In the meantime, this phenomenon may also affect the "drop-out" assays resulting in false-positives, reinforcing the need in direct detection. Overall, the displayed results indicate that the developed assay can be employed and provide essential, direct detection abilities for the two variants. 
medRxiv preprint doi: https://doi.org/10.1101/2021.02.25.21252454; this version posted March 1, 2021. The copyright holder for this preprint (which was not certified by peer review) is the author/funder, who has granted medRxiv a license to display the preprint in perpetuity.

All rights reserved. No reuse allowed without permission.

Table 3. Detection sets results when employed on positive template, negative template or a wastewater sample.

\begin{tabular}{|c|c|c|c|c|c|}
\hline Sample & $\begin{array}{c}\text { Sample date } \\
\text { collected }\end{array}$ & $\begin{array}{c}\text { S1 set } \\
\mathrm{Ct}\end{array}$ & $\begin{array}{c}\mathrm{S} \Delta 69 \text { set } \\
\mathrm{Ct}\end{array}$ & $\begin{array}{c}\mathrm{S} \Delta 241 \mathrm{set} \\
\mathrm{Ct}\end{array}$ & $\begin{array}{c}\text { CDC N2 } \\
\mathrm{Ct}\end{array}$ \\
\hline $\begin{array}{c}10^{3} \mathrm{~S} \text { gene Original } \\
\text { template }\end{array}$ & & 28.61 & $N D^{* *}$ & $N D^{* *}$ & $N D^{* *}$ \\
\hline $\begin{array}{c}10^{3} \mathrm{~S} \text { gene deletion } \\
\text { template }\end{array}$ & - & $N D^{* *}$ & 30.29 & 29.94 & $N D^{\star *}$ \\
\hline WWTP* Beer-Sheva & $\begin{array}{c}\text { November } 17 \text {, } \\
2020\end{array}$ & 36.23 & $N D^{* *}$ & $N D^{* *}$ & 31.88 \\
\hline WWTP* Beer-Sheva & $\begin{array}{c}\text { December } 8 \\
2020\end{array}$ & 35.16 & $N D^{* *}$ & $N D^{* *}$ & 33.89 \\
\hline WWTP* Beer-Sheva & $\begin{array}{l}\text { February } 4 \\
2021\end{array}$ & $N D^{* *}$ & 41 & ND & 33.5 \\
\hline
\end{tabular}

*WWTP-Wastewater treatment plant; **ND-Not Detected

\section{Conclusions}

The ongoing concern regarding the COVID-19 pandemic and the emergence of new variants with higher infection rate and morbidity, create great global concern. With regards to the highly dominant variants of concern, British variant B.1.1.7 and South Africa variant B.1.351, current diagnostic tools are expensive, time-consuming or indirect. Here we present an RT-qPCR assay developed for the direct detection of these two variants. An RT-qPCR assay was developed for the direct detection of the British variant (B.1.1.7) and its differentiation from the original SARS-CoV-2 (NC_045512.2). Using a single set comprised of two new primers, two new probes were designed and validated, focusing on the characterized deletion area known as $\Delta 69-70$. In addition, an RT-qPCR direct detection assay was developed for the South Africa variant (B.1.351), using two new primers focusing on a characterized deletion area known as $\Delta 241-243$, and a third probe was designed and validated. The presented primers and probe sets may be used as described here, or even combined in the future in different combinatorial approaches for rapid, cost-effective and direct detection of the two variants. 
medRxiv preprint doi: https://doi.org/10.1101/2021.02.25.21252454; this version posted March 1, 2021. The copyright holder for this preprint (which was not certified by peer review) is the author/funder, who has granted medRxiv a license to display the preprint in perpetuity.

\section{Author Contributions}

K.Y. and E.O. share equal contribution to this manuscript. K.Y. designed sequence, conceived, performed and analyzed experiments and authored this manuscript. E.O. designed sequence, conceived and analyzed experiments and authored this manuscript. N.P. and N.S.B. took part in experiments execution. A.K. conceived experiments, supervised, provided research facilities and edited the manuscript.

\section{Funding Sources}

We would like to acknowledge funding from Ben Gurion University, The Corona Challenge Covid-19 (https://in.bgu.ac.il/en/corona-challenge/Pages/default.aspx) and funding from the Israeli ministry of Health.

\section{References}

Andrés C, Garcia-Cehic D, Gregori J, Piñana M, Rodriguez-Frias F, Guerrero-Murillo M, Esperalba J, Rando A, Goterris L, Codina MG, Quer S, Martín MC, Campins M, Ferrer R, Almirante B, Esteban JI, Pumarola T, Antón A, Quer J. 2020. Naturally occurring SARS$\mathrm{CoV}-2$ gene deletions close to the spike $\mathrm{S} 1 / \mathrm{S} 2$ cleavage site in the viral quasispecies of COVID19 patients. Emerg. Microbes Infect. 9:1900-1911.

Bar-Or I, Yaniv K, Shagan M, Ozer E, Erster O, Mendelson E, Mannasse B, Shirazi R, Kramarsky-Winter E, Nir O, Abu-Ali H, Ronen Z, Rinott E, Lewis YE, Friedler E, Bitkover E, Paitan Y, Berchenko Y, Kushmaro A. 2020. Regressing SARS-CoV-2 sewage measurements onto COVID-19 burden in the population: A proof-of-concept for quantitative environmental surveillance. medRxiv:1-11.

Dreier J, Störmer M, Kleesiek K. 2005. Use of bacteriophage MS2 as an internal control in viral reverse transcription-PCR assays. J. Clin. Microbiol. 43:4551-4557.

Khan MI, Khan ZA, Baig MH, Ahmad I, Farouk AEA, Song YG, Dong JJ. 2020. Comparative genome analysis of novel coronavirus (SARS-CoV-2) from different geographical locations and the effect of mutations on major target proteins: An in silico insight. PLoS One 15:118. http://dx.doi.org/10.1371/journal.pone.0238344.

Kovacova V, Boršová K, Paul ED, Radvanszka M, Hajdu R, Čabanová V, Sláviková M, Ličková M, Lukáčiková L', Belák A, Roussier L, Kostičová M, Líšková A, Mad'arová L, 
medRxiv preprint doi: https://doi.org/10.1101/2021.02.25.21252454; this version posted March 1, 2021. The copyright holder for this preprint

Štefkovičová M, Reizigová L, Nováková E, Sabaka P, Koščálová A, Brejová B, Vinař T, Nosek J, Čekan P, Klempa B. 2021. A novel, room temperature-stable, multiplexed RTqPCR assay to distinguish lineage B.1.1.7 from the remaining SARS-CoV-2 lineages. medRxiv:2021.02.09.21251168.

http://medrxiv.org/content/early/2021/02/12/2021.02.09.21251168.abstract.

Lu X, Wang L, Sakthivel SK, Whitaker B, Murray J, Kamili S, Lynch B, Malapati L, Burke SA, Harcourt J, Tamin A, Thornburg NJ, Villanueva JM, Lindstrom S. 2020. US CDC real-time reverse transcription PCR panel for detection of severe acute respiratory syndrome Coronavirus 2. Emerg. Infect. Dis. 26:1654-1665.

Shu Y, McCauley J. 2017. GISAID: Global initiative on sharing all influenza data - from vision to reality. Eurosurveillance 22:2-4.

Vogels CBF, Brito AF, Wyllie AL, Fauver JR, Ott IM, Kalinich CC, Petrone ME, CasanovasMassana A, Catherine Muenker M, Moore AJ, Klein J, Lu P, Lu-Culligan A, Jiang X, Kim DJ, Kudo E, Mao T, Moriyama M, Oh JE, Park A, Silva J, Song E, Takahashi T, Taura M, Tokuyama M, Venkataraman A, Weizman O El, Wong P, Yang Y, Cheemarla NR, White EB, Lapidus S, Earnest R, Geng B, Vijayakumar P, Odio C, Fournier J, Bermejo S, Farhadian S, Dela Cruz CS, Iwasaki A, Ko AI, Landry ML, Foxman EF, Grubaugh ND. 2020. Analytical sensitivity and efficiency comparisons of SARS-CoV-2 RT-qPCR primerprobe sets. Nat. Microbiol. 5:1299-1305. http://dx.doi.org/10.1038/s41564-020-0761-6. Vogels CB, Breban M, Alpert T, Petrone ME, Watkins AE, Hodcroft EB, Mason CE, Khullar G, Metti J, Dudley JT, MacKay MJ, Nash M, Wang J, Liu C, Hui P, Murphy S, Neal C, Laszlo E, Landry ML, Muyombwe A, Downing R, Razeq J, Neher RA, Fauver JR, Grubaugh ND. 2021. PCR assay to enhance global surveillance for SARS-CoV-2 variants of concern. medRxiv 351:2021.01.28.21250486. https://doi.org/10.1101/2021.01.28.21250486.

Wang P, Liu L, Iketani S, Luo Y, Guo Y, Wang M, Yu J, Zhang B, Kwong PD, Graham BS, Mascola JR, Chang JY, Yin MT, Sobieszczyk M, Kyratsous CA, Shapiro L, Sheng Z, Nair MS, Huang Y, Ho DD. 2021. Increased Resistance of SARS-CoV-2 Variants B.1.351 and B.1.1.7 to Antibody Neutralization. bioRxiv. 
Original (NC_045512)

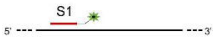

British (B.1.1.7)

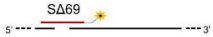

South Africa (SA) (B. 1.351)
$\mathrm{S} \triangle 241$

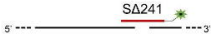

GTTCTTACCTITCTIITCCAATGTTAC

Reverse R21828

CCATCATTAAATGGTAGGACAGGG

Fonward F22243

AGATTTGCCAATAGGTATTAACATC

Reverse R22331

CTGAAGAAGAATCACCAGGAGTC

S1

FAM/TCGTTCCAT/ZEN/CTATACATGTCTCTGG/3 LABKO

S. 69

YakYeUTGGTICCATJZENGCTATCTCTGGGACC/3LABKO

$\mathbf{S} 1241$

FAMICTAGGTTTCZENAAACTTACATAGAAGTT/3IABKFQ 


\section{$S \triangle 241$}
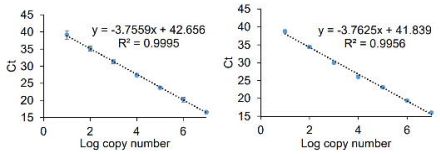

51

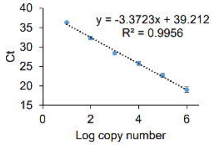


S169

\section{S 1241}
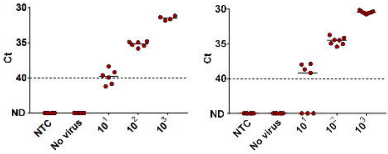

S1

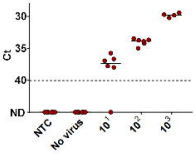

